\title{
The Pilgrimage Landscape in Contemporary Estonia: New Routes, Narratives, and Re-Christianization
}

\author{
Tiina Sepp \\ Institute of Cultural Research, University of Tartu, Tartu, Estonia \\ tiina.sepp@ut.ee \\ Atko Remmel \\ School of Theology and Religious Studies, University of Tartu, Tartu, Estonia \\ atko.remmel@ut.ee
}

\begin{abstract}
This article is the first attempt at mapping the pilgrimage landscape in contemporary Estonia, reputedly one of the most secularized countries in Europe. Based on fieldwork on three case studies - the Estonian Society of the Friends of the Camino de Santiago, the Pirita-Vastseliina pilgrim trail, and the "Mobile Congregation" — we have identified three distinctive features that shape the Estonian pilgrimage scene. The processes of Caminoization and heritagization characterize pilgrimage on a European scale, while the phenomenon that we call "bridging" has a more local flavor. Bridging refers to using pilgrimage to create connections between the Church (of any Christian denomination) and "secular" people. Historically a Christian practice, pilgrimage has transformed into something much more ambiguous. Thus, people often perceive pilgrimage as religion-related but still inherently secular. As the relationships between institutionalized religion and the vernacular world of beliefs and practices are multivalent, there is evidence of an ongoing "re-Christianization" of pilgrimage.
\end{abstract}

\section{Keywords}

contemporary pilgrimage - Caminoization - heritagization - bridging Estonia - re-Christianization 
Most of the analyses of the religious landscape in contemporary Estonia refer in one way or another to extreme secularization (Pickel, Pollack, and Müller 2012). Yet against this background, pilgrimages have emerged as a form of semisecular/semireligious practice. Historically a Protestant country, one cannot speak of an Estonian tradition of pilgrimage. Information about medieval pilgrim routes in Estonia is extremely scant; hence, there are no routes to be revived. Nevertheless, in recent decades, there has been a considerable increase in pilgrimage activities in Estonia, both on a global and a local scale. Every summer there is a Catholic pilgrimage to St. Mary's Chapel in Viru-Nigula. It starts with a Mass in the village church and is followed by a two-kilometer procession to the ruined 13th-century chapel. In the 199os, going on a pilgrimage to Taizé, usually by bus, became popular among Estonians (Altnurme 2012). More recently, congregations have started to make pilgrimages to Jerusalem and Rome and several other places. Groups as well as individual pilgrims fly to Spain to walk the Camino de Santiago. On a local scale, due to the lack of knowledge about medieval pilgrim trails, new routes have been created, which attract increasing numbers of pilgrims from Estonia as well as abroad.

This article is the first attempt at mapping the pilgrimage landscape in contemporary Estonia. It will investigate the development of pilgrimages in the making, highlighting three distinctive features that shape the pilgrimage scene, all taking place "glocally." While Caminoization and heritagization characterize pilgrimage on the European scale, the phenomenon that we call "bridging" has a more local, Estonian flavor. We draw on fieldwork from three case studies that refer to both new trails and new organizations:

- The Pirita-Vastseliina pilgrimage trail is the biggest recent addition to the Estonian pilgrimage landscape. Work on the trail started in 2012. This route of over $450 \mathrm{~km}$ starts in the Catholic Pirita (St. Bridget's) Convent in Tallinn and ends in the ruined Vastseliina chapel in south-east Estonia. ${ }^{1}$

- The Estonian Society of the Friends of St. James Way was founded in early 2015, although their pilgrimages and pilgrim reunions started a few years prior to the formation of the Society. ${ }^{2}$

- The small, informal "Mobile Congregation" (Rändkogudus) also started in 2012. Their activities include looking after four or five Orthodox cemeteries and two churches and visiting sacred sites in Estonia and abroad. Their name "Mobile Congregation" derives from their use of a minibus to get from one place to another.

1 See http://www.palverand.ee//lang/en/ (accessed 18 May 2020).

2 See http://camino.ee/ (accessed 18 May 2020). 
Due to being fairly recent developments, these cases offer us an ideal "laboratory" for exploring the revival and recreation of pilgrimage in Estonia. Apart from participant observation, we have conducted semistructured interviews and email interviews with both organizers and users and monitored pilgrimage websites and Facebook groups.

In the following, we will provide background for understanding the position of religion and pilgrimages in Estonia and then give a short overview of the new meanings that pilgrimage has acquired. After that we will move on to explore the emergence of new trends in pilgrimage practices: Caminoization, heritagization, and bridging.

\section{1 \\ A Short Excursus to the Religious Situation in Estonia}

Being a border state between East and West makes Estonia distinguishable from a "typical" Western European example. Thus, a short excursus into the position of religion in Estonian society is in order. First, one should mention the problematic image of Christianity in the Estonian national narrative, a story about "Estonianness." The backbone of this story, formed in the 19th century, is the Estonians' fight for freedom and the endurance of Estonian culture. This story is sometimes identified as a "golden age" type, longing for the past (Annus 2000; Jonuks 2019). However, this golden age is set in pre-Christian times, and the Church is blamed for its demise as a henchman of the foreign oppressors that ruled Estonians during the "seven-hundred-year-long night of slavery" - a reference to the age after the Nordic crusades in the 13th century when Estonia was ruled by different foreign powers (Tamm 2008). As a result, there is no overlap between Christianity and Estonian national identity. If there is an overlap between religion and Estonian identity at all, it would be with a neopagan maausk (earth belief), conceptualized as Estonian native or ethnic religion (Västrik 2015), which has a clear anti-Christian attitude.

Other important features of the Estonian religious landscape derive from the Soviet experience. Being occupied by the Soviet Union after the Second World War until 1991, Estonia became a subject of the Soviet antireligious policy. Unlike some other parts of the Soviet Union, where religious and national identity were strongly connected, the churches in Estonia did not put up much of a fight. Thus, in the 196os religion was pushed out of the public sphere while effectively cutting off the continuation of religious socialization and traditions. This "religious gap," which lasted until the end of the 1980s, rendered nonreligiosity normative. At the same time, the Soviet propagandists exploited Estonians' uneasy relationship with Christianity in their attempts 
to make the Soviet version of atheism more acceptable to the Estonians. To show Christianity as alien and atheism as an inherent part of Estonian culture, church-critical Estonian intellectuals from the past were presented as atheists and Estonian folklore as inherently antireligious, therefore claiming Estonians to be a "historically religiously lukewarm nation" (Tarand 1961: 11). The Soviet atheistic project is generally considered a failure (Smolkin 2018), but it seems that it was successful at least in altering the position of religion in society. Even today, when interpreting the recent statistic on religion, Estonians are often (self-)referred to as "the least religious/most atheist nation in the world," which to some extent seems to have become a part of national identity.

Indeed, in terms of belief in God or religious identity, Estonia appears in the lowest parts of the charts. According to Eurobarometer (2005), only 16 percent of Estonians believed in God, and only 29 percent of the population considered themselves to have "some religion of their own" (Estonian Census 2011). Both indicators are quite low in comparison to most European countries. Also, the situation in the public perception toward religion has not changed much since Estonia regained independence in 1991; as the visibility of religion in Estonia is still low, religious illiteracy is widespread, and being religious is far from being socially desirable. Even the semantics of religion-related terminology is often negative: for example, "believer" (usklik) is associated with mental abnormality and "religion" (religioon) has connotations with brainwashing. As a result, Ringvee states that "secularization and secularity seem to be inherent features" of Estonian society, also noting that "general indifference concerning religion in all of its aspects prevails" (2017: 57). Perhaps this is also the reason why there has been no controversy over the increasing popularity of pilgrimage.

Concurrently, the extreme secularization of Estonian society can be questioned on the basis of individualization theory and the popularity of alternative forms of religion. For instance, the same Eurobarometer survey (2005) that revealed the low popularity of belief in a personal God showed that 54 percent of Estonians believed in "some sort of spirit or life force." Analyzing the changes in the religious landscape, this strand of research claims that alternative spiritualities in Estonia are on their way to becoming a mainstream religion (Uibu 2016). Indeed, most of the contemporary statistics can inspire interpretations about Christianity or the lack of it, but they leave out most of the richness of everyday (Ammerman 2007) or vernacular (Bowman and Valk 2014) forms of both "religion" and "secularity." Within this gray area of lived (non) religion, different and even opposite processes take place.

On the one hand, in line with secularization theory, the lack of religious socialization has led to general religious illiteracy, and one could argue that (traditional) religion is on its way to being separated from culture (Roy 2010). 
To denote the changing position of religion, especially in the Scandinavian context, a concept of "cultural Christianity" has been proposed, which points to the "sense of personal identity and continuity with the past even after participation in ritual and belief have lapsed" (Demerath 2000: 127) or to religious commitment linked to a cultural heritage (Kasselstrand 2015). Here, "culture" is used in the sense of "more secular" or "diluted." Yet in Estonian media and also in interviews with nonreligious people (Remmel $2019 \mathrm{~b}$ ), even a differentiation between "religion" and "culture" can be observed - culture is seen as differentiated from religion, areligious, or even opposed to religion. These distinctions are mostly implicit, but sometimes they are explicitly stated. A good example is the comment of the Minister of Culture, Indrek Saar, on the Estonian government's recent decision not to return St. Nicholas Church in Tallinn - which had been transformed into a museum during the Soviet era - to the Estonian Lutheran Church: "The solution will certainly be gratifying for all friends of culture both in Estonia and abroad" (BNS 2018).

On the other hand, during the last decade, the position of religion in Estonia has begun to change. In conjunction with global developments, such as the migrant crisis that peaked in 2015, and with domestic changes, such as the election of a young and active Archbishop of the Estonian Evangelical Lutheran Church, Urmas Viilma, in late 2014, the visibility of religion has somewhat increased; news about religion regularly appears in local media, and there are also signs that people are more willing to self-identify as religious, which points to the fading negative "aura" of the religious sphere.

After the Reformation the popularity of pilgrimage decreased significantly. In the 2oth century, however, the practice of pilgrimage has been revived. At a time of dwindling congregations, the idea of going on a pilgrimage appeals to increasing numbers of people from different backgrounds. As a complex and multilayered practice, contemporary pilgrimage is characterized by a strong sense of ambiguity (Bowman and Sepp 2019; Coleman and Bowman 2019). People going on pilgrimages may self-identify as pilgrims, seekers, hikers, and so on. These categories sometimes overlap, and the lines between them are often porous, with people moving from one category to the other. Peter Jan Margry suggests that travelers on spiritual routes are "quite puzzled about what they are, what they are searching for and what they are actually performing, and how this act relates to the traditional Christian conception of pilgrimage" (2015: 176). Reflecting on the role of pilgrimage in Anglican cathedrals, 
Coleman and Bowman (2019:30) note that there is the question of how and whether a post-Reformation institution should be encouraging such activity, and, more generally, how far the Church of England can reappropriate medieval practices of piety. Some Anglicans still associate saints and pilgrimage with Catholicism and find their re-emergence in the Church of England difficult to come to terms with (see Sepp 2019).

The reasons for the surge in pilgrimage in Europe are manifold. Where the Christian Churches seem to be failing to connect with people, more and more individuals are finding their spiritual needs (such as a sense of community) met elsewhere, often on pilgrim trails. People going on pilgrimages find a huge range of meanings in the pilgrim traditions, physical challenges, and interpersonal encounters they experience along the way. Pilgrimage defined as a "journey to a sacred place" is just one of the many conceptions of the term. Many pilgrims feel that they are "walking in other people's footsteps" without having their predecessors' confessional worldview (Bowman and Sepp 2019; Frey 1998). One of the most significant phenomena influencing the revival of the pilgrimages is the Camino de Santiago de Compostela, which has been assigned as a Cultural Route of the Council of Europe (in 1987) and designated as a Unesco Cultural Itinerary (in 1998). In the Western world, the Camino's popularity has led to the domination of one pilgrimage model, as the Camino is now regarded as the "prototypical" pilgrimage. Santiago pilgrims often start "importing" the Camino to their native country, which has led to the revival of ancient pilgrimage routes as well as the development of new ones. Caminoization also refers to the assumptions that journeying and physical exertion are the mark of the true pilgrim and are as important to pilgrimage as the destination itself (Bowman and Sepp 2019). This goes hand-in-hand with the "spiritualisation of walking" (see Österlund-Pötzsch 2010), whereby walking is seen as inherently "spiritual" outside any formally religious framework. Dionigi and Eade (2015:9) remind us to examine not just the ways in which places become sacred but also how routes are sacralized. The new pilgrim paths are "routes with roots," heritagized manifestations of a lost (and often idealized) history, encouraging access to rural areas and neglected cultural heritage, usually with complex agendas (Bowman and Sepp 2019: 81). Analyzing religiosity in contemporary Poland, Anna Niedźwiedź brings out the popular current of Polish Catholicism mixed with "national megalomania" as one of its main characteristics. Furthermore, the landscape is also perceived very much in a national framework (Niedźwiedź 2014: 98-99). In Estonia, too, many topics are interpreted through the prism of nation(alism), and we can also see the development of a national take on pilgrimage, for instance, the pilgrimages devoted to the centenary of the Estonian Republic. 
Looking at the ways in which pilgrimage is being re-presented and how local pilgrim paths are being developed, it becomes clear that the Camino has had a huge impact on the Estonian pilgrimage landscape, and we can certainly speak about Caminoization. Jane Vain, who has studied pilgrimage coverage in the Estonian media in the period 2000-2015 argues that for the secular press and general audience the Camino de Santiago and any other pilgrimage mean one and the same thing. She notes: "Going on pilgrimage means going to the Camino de Santiago, unless stated otherwise" (2015: 28). The role of popular culture (books and films) in the process of Caminoization cannot be overemphasized. Probably the most influential book about the Santiago pilgrimage has been Paulo Coelho's The Pilgrimage: The Diary of a Magician (first published in 1987). Its translation into Estonian in 2002 paved the way for the Estonian "Camino boom." Indeed, in September 2017, a pilgrimage day was held in Vastseliina Episcopal Castle, with the aim of drawing more attention to the recently established Pirita-Vastseliina pilgrim trail. The newsreader reporting the event on Estonian Television started with the following words: "For more than three years Estonia has had its own Santiago de Compostela, or pilgrimage trail, but this is not very well known" (Aktuaalne Kaamera 2017).

Another aspect of Caminoization is the grassroots activism of Camino "veterans," which points to the importance of individuals in shaping the local pilgrimage culture. For example, Epp Sokk and Jane Vain — both members of the Pärnu-Jakobi congregation of the Estonian Evangelical Lutheran Church have played a major role in promoting the Santiago pilgrimage in Estonia. ${ }^{3}$ Epp shared with us the story about her "conversion" to the Camino de Santiago. In January 2007 she went to Tallinn to talk to the (then) archbishop about some issues in her home congregation in Pärnu-Jaagupi. Before getting on a bus to return to Pärnu-Jaagupi, Epp bought a book from the bus station, which happened to be Peregrina päevik (A Pilgrim's Diary) by Tiina Sepp (2007). By the time she got home, Epp had finished reading the book and made up her mind to walk the Camino. In her own words:

I had gone to the Archbishop to ask what we were supposed to do here in [Pärnu-]Jaagupi. Then I went to the bus station and I was given, here you are, here is your booklet. That is what you should do. And since then I have been doing it ... It was as if I was given that book and told, "you start doing these things, and this is now your path." ... I felt that my Jakobi

3 Since August 2019, Jane has served as a deacon. 
church was connected with the St. James's church there, that the Spanish Santiago was calling me, that I had to reach Santiago because there were answers to the questions I was currently having. ${ }^{4}$

After walking the Camino de Santiago, both Epp and Jane became pilgrimage enthusiasts and started to organize pilgrimages in Estonia as well. They started a Facebook community to unite former and prospective Estonian Santiago Pilgrims, and both are founders of the Estonian Society of the Friends of the St. James Way. Indeed, another aspect of Caminoization is the emergence of St. James Confraternity-type organizations. The Estonian Society of the Friends of the St. James Way organizes annual pilgrim reunions and pilgrimages, starting on the weekend closest to St. James Day on 25 July. They are creating new pilgrim paths in Estonia, where yellow arrows are used as waymarks, and Compostela-like certificates are given to people who have completed the pilgrimage (the emergence of this kind of material culture is another distinctive feature of Caminoization). They have created a virtual map of a pilgrimage trail signed with scallop shells going from Tallinn to the Latvian border; this "Camino Estonia" is part of the European network of pilgrim routes. Together with pilgrims from other Baltic countries, Latvia and Lithuania, they are working on the Camino Via Baltica. They have organized a foot pilgrimage from Pärnu-Jaagupi to St. James church in Riga; between 2009 and 2014, Epp and Jane made a pilgrimage to cover all St. James's churches in Estonia. Jane said that it is important to walk towards a church that has been consecrated to St. James: "You are doing the same [as] you did in Spain." Furthermore, Epp and Jane are planning to walk from Estonia to Spain, from the Pärnu-Jakobi church to Santiago de Compostela. They said that they want to go from "our James to the real James." ${ }^{5}$

Another example of grassroots activism is the case of a Lutheran vicar, Tauno Toompuu, whose motive for walking the Camino was an interesting one: being awarded the Clergyman of the Year title (of the Estonian Evangelical Lutheran Church), he was given a sum of money to spend on a journey to a destination of his choice. He decided to go to Spain and walk the Camino, and since then he has acted as a "Camino missionary" in Estonia:

After walking the Camino, I have shared my experience with lots of people. I think I have talked at about 20 events. I see it as a kind of mission.

4 Epp Sokk, interview January 2015. All the interviews were conducted in Estonian but were translated by the authors of this article.

5 Jane Vain, interview January 2015. 
After finishing the Camino, I felt as if I owed something to the Camino. Having gained so much, I have tried to give at least something back. By talking about it and encouraging people to do the Camino, I am trying to pay off my debt. I think that the more people go to the Camino the better ... With regard to Christians, it also depends on their spirituality. People with Free Church background put more value on visiting Israel and Jerusalem; the Catholics would often go to Rome. Perhaps the Camino is most popular among Lutherans and secular travellers. I agree with a German fellow pilgrim who said he was happy that so many Germans walked the Camino because it makes Germany a better place. I also think that the more Estonians go to the Camino the better it is for our society, because people who come back from the Camino are very likely to be slightly better human beings. ${ }^{6}$

The Camino and the Caminoized routes it has inspired have become the exemplars of 21st-century experiential travel, walking with intent, combining "mobility itself with a degree of reflexivity as to its meaning, form and function" (Coleman and Eade 2004: 18; Bowman and Sepp 2019: 94). However, despite the Camino being the main model for local pilgrimages, not everybody thinks that pilgrimage needs to involve a long and arduous journey on foot. We have identified tendencies that can be referred to as "non-Caminoization." The term was introduced by Simon Coleman to refer to pilgrimage activities that do not reflect the Camino and are in conscious opposition to that type of pilgrimage. ${ }^{7}$ In the Estonian context, the case of the "Mobile Congregation" serves as an example. This informal "congregation" was born thanks to its members' (genealogical and other) interest in Orthodox churches and cemeteries, which led them to take care of four or five more or less neglected Orthodox cemeteries. The group has grown in number (from five to fifteen members currently), and they have also invited local people to join their activities at the cemeteries. Since 2012, when the "Mobile Congregation" was formed, they have made several trips by minibus in Estonia and abroad (for example, Poland, Belarus, Ukraine) visiting churches and other sacred sites.

Their appearance on the Estonian pilgrimage scene is a rather impromptu one and illustrates the vagueness and constant redefinition of the pilgrimage discourse. In 2017, the group made a bus trip to Russia with the aim of visiting some of the Orthodox churches. Ahead of the journey, they did not give much thought to how to call themselves or their trip, but when a Russian customs

6 Tauno Toompuu, email August 2017.

7 Personal communication with Tiina Sepp, 2015 . 
officer asked them about the purpose of their visit, the group leader, whom we will call Jüri, said they were pilgrims. This is how he put it to us:

I said impulsively "my palomniki” [in Russian: we are pilgrims]. We didn't discuss that before. I just said the word and now it's a pilgrimage wherever we go ... We knew by that time that we would visit only churches and avoid museums ... due to the lack of time and also because some people get tired in the museums. ${ }^{8}$

No further questions were asked by the customs officer, and from that moment on, they decided to call themselves pilgrims. In their experience, the status of a pilgrim gave them protection in a foreign land. Indeed, they even asked a Russian priest to bless their minibus at the beginning of the journey, which can be seen as an example of a pilgrim's label leading toward religious practices. Using a motorized vehicle clearly illustrates the importance of the destination as opposed to that of the journey. How one gets to the destination is irrelevant; the only things that matter are the destination itself and the activities that one does there - a clear example of non-Caminoization. Another distinguishing feature of the "Mobile Congregation" is their "eastward orientation" in the sense that unlike the overwhelming majority of Estonian pilgrims, they are not particularly interested in the Camino de Santiago or other Western European destinations. They are drawn toward the East and Orthodox churches and cemeteries.

Turning into pilgrims rather spontaneously on the Russian border is just one piece in the fascinating puzzle of the Mobile Congregation's pilgrimage. In January 2018, Jüri and two of his fellow pilgrims from the Mobile Congregation were invited to give a talk at a seminar about their recent pilgrimage to Russia. The focus of their talk was solely on the architecture of the churches, and there was hardly any mention of anything spiritual. Stausberg mentions "touristification of pilgrimage" and the "pilgrimization of tourism," pointing out that "the distinction between pilgrimage and tourism is often blurred in travel practice" (2011: 64). Probably for the same reason, after the talk, a member of the audience asked them what distinguished their pilgrimage from an excursion. The speakers seemed slightly upset by the question and replied that it was a

8 "Jüri," interview September 2019. 
pilgrimage "because they had only visited churches." The questions that followed about the spiritual side of their pilgrimage also remained unanswered.

Initially we thought that their reluctance to elaborate on their answers was caused by the public situation, but apparently this hesitation is very much present in the private sphere as well. Jüri has pointed out that he does not know what the other members of the group believe in, because they never discuss spiritual matters with each other. ${ }^{9}$ At first glance this case seems to illustrate something that we might call "keeping religion out of pilgrimage." This approach might be exemplary in the case of atheists and other secular people who are more interested in aspects of horizontal transcendences (desire to connect to nature and one's deeper self within the framework of naturalistic ontology) during the pilgrimages (Farias et al. 2019). Yet the members of the Mobile Congregation hardly fit this group, as religion seems to be present in their life in one way or another. Apart from looking after cemeteries and campaigning for the preservation of churches with the Mobile Congregation, Jüri is a voluntary caretaker and bell ringer at an Estonian Orthodox parish where his father used to serve as a priest; he also sings in the choir of a Lutheran church. ${ }^{10}$ In the last couple of years, an Orthodox priest, who often joins the group in tidying the cemeteries, has baptized four people of the Mobile Congregation.

When asked about his reluctance to discuss spiritual topics, Jüri commented:

I'm not even going to start these conversations because I fear that we might have quite different opinions and it might lower my opinion of them. I am cautious in this respect. However, if someone decides to clear up a cemetery or the surroundings of a church then this is a very sensible thing to do. If you then start to untangle religious topics, it's very easy to fall out. Some people are quite stuck in their opinions and are not easily influenced. All in all, religious people are quite conservative, if they are really religious, churchgoers. It's better not to touch the subject ... To be honest, I don't even know if, for example, this person is baptized. ${ }^{11}$

We found these so-called "silent pilgrimages," where the spiritual remains unspoken, rather intriguing. Why does Jüri prefer not to talk about spirituality, not even with his friends? Why has he decided that spiritual topics "should

9 "Jüri," interview September 2019.

10 There are two Orthodox churches in Estonia: the Estonian Apostolic Orthodox Church under the jurisdiction of the Patriarchate of Constantinople, generally considered the "Estonian" church, and the Estonian Orthodox Church of the Moscow Patriarchate, generally considered the "Russian" church.

"Jüri," interview September 2019. 
not belong to the verbal realm" (Seljamaa 2016: 28; see also Bateson and Bateson 2005: 80)?

To some extent, Jüri's reluctance to discuss spiritual matters can be explained by the somewhat negative image of religion in the Estonian context. Pihla Maria Siim, who has studied unsaid or unsayable things in family histories, speaks about "protective silence" (2016: 80). She notes that concealing their ethnic or religious background from people outside the family was important for the Finns as well as other ethnic and religious groups living in the Soviet Union - especially under the Stalin regime. Talking about one's ethnic or religious affiliations could have caused problems. As his father had been a priest, during the Soviet period it was probably vital for Jüri to keep silent about certain things. Siim has observed that while silenced stories can emerge when the societal situation changes, certain themes may remain taboo, as the habit of keeping silent about certain things is persistent (85).

Still, the interview indicates that the spiritual side in the activities of the Mobile Congregation is not absent at all; it is just expressed in a different way. Jüri tells us that the people in the group are "drawn" by the atmosphere of the cemetery:

And we have our meals there, on the graveyard. It is not strange for us at all. We don't go to a diner or cafe ... Well, we are there, in the middle of the crosses. On our ancestors' bones, stumping, so to say ... and it is a special feeling. And, of course, the joy that we can put things in order in the cemetery usually within one day. There are so many of us that we can get it done. ${ }^{12}$

Jüri has not been to any organized Orthodox pilgrimages. However, he told us that in the summer one member of the group went on the pilgrimage on Muhu Island, taking in two Lutheran and one Orthodox church. Jüri described that pilgrimage thus: "To my mind, this is in some ways less meaningful. I actually like this work [on the cemeteries] because as a result the place becomes clean and orderly."13 In other words, the consequences of walking from one church to another are not as remarkable as getting the cemeteries clean and tidy. Jüri prioritizing the physical work in the cemeteries over walking pilgrimages provides a good example of non-Caminoization.

12 "Jüri," interview September 2019.

13 "Jüri," interview September 2019. 


\section{Heritagization — Forging Connections between Past and Present}

One of the phenomena that often goes hand-in-hand with Caminoization is heritagization, whereby material culture, places, and praxis from the past are made - or presented as - meaningful in the present (cf. Harrison 2012). Indeed, the Camino de Santiago is a perfect example of heritagization (see Margry 2008; Sánchez-Carretero 2013). Exploring the heritagization of religion and the spiritualization of heritage in traditionally Protestant countries, Bowman and Sepp (2019: 95) argue that the appeal of "routes with roots" appears large, as people cast themselves as spiritual heirs of a pilgrimage tradition largely seen through the lens of the re-presentation of the Camino de Santiago. They note:

Perhaps it is the heritagisation aspect of the Camino that enables people to feel heirs to it, participate in it, feel part of a long tradition of spiritual travellers (though their worldviews are not those of medieval or even contemporary Catholics/Christians), use the infrastructure of the Catholic Church (which they might normally distance themselves from), value the credencial and Compostela (although they may not normally describe themselves as religious, and have no interest in indulgences) and attend the Pilgrim Mass, seek a pilgrim blessing or participate in the "pilgrim tradition" of hugging the statue of St. James on arrival at Santiago Cathedral (even though they want or expect nothing from him).

BOWMAN AND SEPP 2019: 80

These processes can be observed in Estonia as well, but again, with local peculiarities. In a context where religion is not considered an inevitable part of culture, heritagization has another layer of meaning: heritage refers to a connection with the culture of the past. This aspect has been addressed from the church's position by emphasizing the role of religion in Estonian history and its contribution to Estonian culture. For instance, expressing his astonishment at the attitude of many Estonians who do not value their 8oo-year-old Christian cultural heritage, Archbishop Urmas Viilma said: "It is our Christian, especially our Lutheran-Protestant worldview that has been the real fountainhead of the printing, literacy, architectural and art heritage, song and music festivals, education and community culture" (Viilma 2015). Yet this is a controversial tactic: while showing religious roots of culture, this approach contributes to a historization of religion, as religion is understood as belonging to history rather than being active in contemporary society. Moreover, this tactic also contributes to making religion "less religious," as only "cultural" or "secular" aspects of religion are emphasized (Remmel 2019a). Nevertheless, this tactic has 
proved to be highly successful in the case of the neopagan movement maausk, institutionalized in the early 199os. By advertising itself as representing "true Estonians' worldview" the movement emphasizes its role of protecting heritage (sacred groves and springs), while the "religious" part of their teachings is entirely secondary, making it acceptable for a wider public. As a result, maausk is perceived as more "culture" than "religion," and in 2014, more than 6o percent agreed that maausk is the true religion of the Estonians (RTE 2014) - a remarkable marketing achievement for such a young (religious) movement (Jonuks and Remmel, forthcoming).

The two case studies provided below show a strong interrelationship between Caminoization, heritagization, and a national take on pilgrimage.

A Pilgrimage Dedicated to Estonia's 1ooth Anniversary

In 1918 Estonia declared its independence from Russia. The first period as an independent republic ended with the Second World War, when the Soviet Union began an occupation of Estonia that lasted for the next 50 years. Estonia's independence was restored in August 1991 in the course of the collapse of the Soviet Union. To mark the 1ooth anniversary of the Republic of Estonia, in 2018 a myriad of events were organized, one of them a pilgrimage organized by the Estonian Society of the Friends of the St. James Way. This pilgrimage, which took place in July 2018, was about $100 \mathrm{~km}$ long, lasted for six days, and was called the "Estonia 100 Pilgrimage. One hundred kilometers, one hundred times, one hundred prayers for Estonia."

The length of the pilgrimage was chosen as a reflection on the 100 years of the Estonian republic. The pilgrimage started in Pärnu, where on 24 February 1918 the declaration of independence was first read out. The pilgrimage ended in Pilistvere, which is associated with the restoration of independence in 1991. It was the eighth pilgrimage organized by the Society, taking place over the weekend closest to St. James day on the $25 \mathrm{July}$. The organizers told us that they were hoping to engage anyone who takes an interest in pilgrimage, walking, and Estonian history and culture. One of the ideas was that some of the local people would join the pilgrims walking through their village. That plan, however, did not succeed - only a few villagers joined in. Altogether there were around 50 participants in the pilgrimage; some only walked part of the way. The organizers, Epp and Jane, suggested that the idea of pilgrimage just does not resonate with everybody yet. ${ }^{14}$ Indeed, wider audiences do not perceive pilgrimages as a part of Estonian culture, since local people sometimes assume 
that pilgrims are foreigners: "It was strange that when we asked to stay overnight, they thought we were foreigners. As if Estonians don't like to discover their own country" (Jaama 2016).

This ecumenical pilgrimage started with a prayer and blessing in the Seventh-Day Adventist Church in Pärnu (because the pastor is a Camino enthusiast and friend of the organizers) and ended in the Lutheran church in Pilistvere. There were morning and evening prayers every day, and a "sharing circle" every evening, during which a little metal figure of St. James was passed round and everybody was invited to say something, to reflect on the day and bring out the highlights. We were told that this led to bonding within the group: people were looking at each other and listening in silence to the person who was speaking. Pilgrims were summing up their day and sharing it with each other, even if it was just to say that they had a lovely swim. Every participant was given a little blue-black-and-white flag (an Estonian national flag), which they could attach to their backpack; several pilgrims also carried a Camino shell. At the end of the pilgrimage, the participants were given certificates with Estonian Republic 100 symbols and a little Celtic prayer ("May the road rise up to meet you. / May the wind be always at your back. / May the sun shine warm upon your face; / the rains fall soft upon your fields and until we meet again, / may God hold you in the palm of His hand"), which has become a common element of the Santiago pilgrimage culture.

One pilgrim told us that she very much liked the national dimension of the walk, all the historical places and old Estonian farmhouses, some over 150 years old. When asked to compare the Camino in Spain with the Estonian Republic 100 pilgrimage, she pointed out the feeling of camaraderie and equality among pilgrims as the main similarity. No matter how old, how rich, how fit, what nationality one was, everybody was equal and prejudices disappeared. The main difference, according to her, was the extent of independence. On the Camino one is entirely free, but the Estonian Republic 100 pilgrimage was carefully planned and regulated, with not much space for improvisation. ${ }^{15}$

The pilgrimage dedicated to Estonia's 1ooth anniversary was a patriotic event, with pilgrims visiting places significant to Estonian history and culture while carrying blue-black-and-white flags. The "Camino vibes" were strongly present: most participants had walked the Camino, and, significantly, the figure of St. James was passed round every evening during the sharing circle. We were told that one of the aims of this and other similar pilgrimages is to send out the message that there are paths and walks in Estonia as well, that one does not necessarily have to go to Spain. The use of an existing annual pilgrimage

15 Interview August 2018. 
format to celebrate Estonia's independence and heritage, together with the mix of national symbols with an old Irish prayer on the pilgrim certificate, reflects the multivalent and rather complex nature of contemporary pilgrimage: "Caminoized in form, national in content."

The biggest recent addition to Estonian pilgrimage landscape is the PiritaVastseliina pilgrimage trail. Described as a "spiritual and cultural-historical journey," the route of over $450 \mathrm{kms}$ starts in the Catholic Pirita (St. Bridget's) Convent in Tallinn and ends in the ruined Vastseliina chapel in south-east Estonia. Both places were important pilgrimage sites in the Middle Ages.

The Pirita Convent, founded in the early $15^{\text {th }}$ century, was destroyed in 1575 during the Livonian War; the exterior walls of the church with a soaring triangular 35-meter-high western gable still survive. In September 2001, a new Bridgettine convent was consecrated on the territory of the old one, next to the ruins. Baptisms, weddings, and funerals have been arranged, and the convent chapel is also open to members of other denominations. The annual Bridgettine Convent Days, plays, seminars, concerts, and so on take place there. The Friends of the Pirita Convent has been founded, which has, among other activities, organized many pilgrimages (Parek, Salo, and Au 2012).

Similarly to Caminoization, the role of specific individuals should also be noted in relation to heritagization. One of the main figures behind the PiritaVastseliina pilgrimage trail is Lagle Parek, a former dissident of the Soviet period and minister of interior affairs after Estonia regained independence in 1991. Parek and the Friends of the Pirita Convent started to work on the Pirita-Vastseliina pilgrimage trail in 2012. Interestingly, the new pilgrim trail has to some extent been inspired and triggered by the Camino de Santiago, although Parek herself has not walked the Camino de Santiago and to some extent distances herself from it.

The other end of the pilgrim trail, Vastseliina Episcopal Castle, has been considered the most significant pilgrimage destination in medieval Estonia (Johansen 1954). In the old ruins of the castle is a medieval holy place, the Holy Cross chapel, where in 1353 the miracle of the White Cross happened:

One September night in 1353, beautiful music was heard from the second floor of the main tower of the empty castle chapel, which was shining in miraculous light coming from two wax candles that had burst into flames 
themselves. The cross had got unstuck from the altar's northern wall and stood in the middle of the altar, totally unsupported. ${ }^{16}$

The Medieval Theme Park at Vastseliina Episcopal Castle recently opened a Pilgrim House, which presents medieval lifestyle related to pilgrims and pilgrimage. The spiritual aspect of the whole complex is strongly emphasized by local guides. The Catholic chapel was founded with the help of Pirita Convent in the basement of a former inn; and it seems to be a popular place to light a candle and just sit and pray or meditate. Yet Vastseliina Episcopal Castle does not enjoy similar popularity as the Pirita Convent, one of the main reasons being its location in the periphery: one has to make an effort to get there.

In the case of this pilgrimage trail, heritagization is one of the central aspects, as the trail is advertised as not solely religious/spiritual but also "culturalhistorical." According to the founder of the pilgrimage trail, Lagle Parek, their aim has been to create a journey that would

offer places of rest and prayer for believers for whom this is a form of serving God, and also for those people who are interested in stories about different periods and people who have lived and worked in our country ... The pilgrimage route is meant for us Estonians as well as people from all over the world who are interested in Estonia's beautiful nature and turbulent history and who are fond of walking.

RAUDVASSAR 2019

Despite these "cultural" passages the trail is very much focused on Estonia's pre-Reformation Catholic heritage.

One of the first things that the Pirita-Vastseliina pilgrim will notice is the lack of waymarks. This intriguing omission is intentional. According to Parek, the reason for this is that they do not want to make the journey too easy. One might wonder if this could have anything to do with the fact that the Camino de Santiago is exceptionally well waymarked. Bearing in mind that Lagle Parek is not exactly a Camino enthusiast, we cannot rule out the possibility that the lack of waymarks is a sign of non-Caminoization. However, there are several prayer benches along the pilgrim trail, the first one in Pirita and the last one in Vastseliina, marking the beginning and the end of the pilgrimage. Also, one can acquire a small pilgrim passport in Pirita to get discounts in places of accommodation. There is no space for stamps in the passport; there is only one stamp on it. The text on the stamp says "Friends of the Pirita Convent: Pilgrim

16 See http://www.palverand.ee/vastseliina-episcopal-castle/ (accessed 19 May 2020). 
trail from Pirita to Vana-Vastseliina. Pilgrim trail from Pirita to Vana-Vastseliina is our present for the 1ooth anniversary of the Republic of Estonia." On the other side of the passport, there is a picture of St. Bridget and the lines of an old Celtic prayer (in Estonian): "Be Thou a smooth way before me, / Be Thou a guiding star above me, / Be Thou a keen eye behind me, / This day, this night, for ever."

Both Pirita and Vastseliina are good examples of "polysemous sites" (Eade and Sallnow 2000) in that they have the power to attract people with a variety of motives and interests. In the Camino context, heritagization mainly refers to people connecting to the long tradition of historical pilgrimage - they put much value on "walking in the footsteps of ancient pilgrims." Heritagization in the Estonian setting, however, means something rather different; it is frequently the "Estonianness" that is celebrated by pilgrims as well as pilgrim organizers. For example, people on the Estonian Republic 100 pilgrimage as well as the Pirita-Vastseliina pilgrim trail have pointed out the importance of visiting historically and culturally significant places, such as old farmhouses and churches. This aspect is also emphasized by Lagle Parek, who has said that thanks to pilgrimage people can discover even less-known places: "Take, for instance, a church at Puutli village - it is in a bad shape, but once you step inside you can feel the history and connection with the past ... Pilgrimage in Estonia is a way of feeling 'Estonianness' and feeling how it was built up in the past" (Jaama 2016).

Bridging: New Connections between Church and Society

Both Caminoization and heritagization highlight an aspect we call bridging, that is, using pilgrimage as a means of creating a connection between the Church and society, between "religious" and "secular." In this sense, pilgrimage can be compared with Christmas, which "possesses the capacity to capture the attention of an otherwise largely apathetic" congregational culture (Coleman, Bowman, and Sepp 2019: 242). Bridging benefits from the ambiguity of pilgrimage, which can mean many different things to different people. At the same time, bridging enforces this ambiguity: the changes in pilgrimage practices go together with the changes in the pilgrimage discourse.

This ambiguity becomes a powerful tool that can be used for a wide range of purposes, intentionally as well as unintentionally. Since the Camino de Santiago is open to all, it is seen as a powerful means of evangelizing by the Catholic Church. This is certainly happening in Spain, where a specific goal of the Catholic Church is to use the popularity of the Camino to evangelize and convert the youth (Frey 1998; Sepp 2014). In April 2013, the first international 
conference dedicated to new evangelization on the Camino de Santiago was held in Santiago de Compostela. In a paper given at this conference, priest Francisco Javier Luengo asked where else we have a phenomenon like this, where thousands of people voluntarily travel on a typically religious route: "Aren't we sighing for more young people in our parishes, movements and associations? Well, here we have them in hundreds" (Luengo 2013: 239-240). Not only are there huge numbers of people, but these people are also involved in the search for something and therefore provide good ground for evangelization (Sepp 2014).

Stella Rock has noted similar trends in Russia, where the Orthodox Church is well aware that a shrine or procession may be the first encounter with Orthodoxy for the "nominally Orthodox" or unbaptized: "Given the opportunities pilgrimage offers for engaging with those who might otherwise be hard to reach, the ecclesiastical hierarchy is keen to ensure that such encounters are managed sensitively." For the curious and the "unchurched," pilgrimage may provide a more palatable taste of Orthodoxy than their local church (Rock 2015: 55-56). This is also true in the Lutheran context in Estonia. The leaders of the Estonian Society of the Friends of the St. James Way have been using pilgrimage and pilgrim reunions to create a bridge between the Church and the "nones." They are aware that talking about pilgrimage from different perspectives highlights Christian symbols and language and can help diminish awkwardness about the Christian Church and lifestyle:

In the space of pilgrimage secular people find themselves next to the Christians ... I have sometimes been told that I am the only religious person they know personally ... Pilgrimage creates a space where they can "smell" the church thing from a safe distance, they see that it does not bite them, and that it is not actually as horrible as it tends to look in the prejudices of many Estonians. ${ }^{17}$

Yet they have had to tread carefully. Jane Vain told us that when they were preparing for the Estonian Republic 100 pilgrimage, one of the organizers suggested that they had better be careful with praying and prayers lest they scared people away. Jane's take on the matter was that "praying is what one does on a pilgrimage." Epp suggested that as the name of the pilgrimage included the words "10o times 100 prayers," people would have known what they were letting themselves in for. Indeed, during the Estonian Republic 100 pilgrimage, everybody attended all the prayers, whether or not they were religious. Speaking of the pilgrimages they had organized, Jane said:

Interview August 2018. 
If you have one or two sacred moments in the day, people will see that there is nothing extraordinary about being a believer, about being a Christian, about praying. All this is part of life and it is okay ... These annual pilgrimages and pilgrim reunions, during which one enters a sacred space, may for some people be the only time in the year that they enter a church. ${ }^{18}$

Although initially a grassroots activity, using pilgrimages in Estonia for bridging has already acquired institutional support. As a follow-up to the "Epp and the Archbishop" story, in early 2016, during one of her visits to Tallinn to speak to the new Archbishop Urmas Viilma, Epp suggested incorporating a Santiago pilgrim blessing into the Pentecost Mass in the Dome Church in Tallinn (the seat of the archbishop, which became Lutheran in 1561). The archbishop was on board almost immediately, and on 15 May 2016 he gave a blessing to pilgrims who were going to walk the Camino in Spain that year - a practice that has become a tradition by now - and in 2019 walked the Camino himself (Viilma 2019). A Lutheran archbishop blessing an originally Catholic practice is another sign of the ambiguity of pilgrimages.

The ambiguity also allows the initial Christian concept to be stretched and applied to "secular" practices. In the spring of 2016, a newspaper article titled "Schoolchildren Went on a Pilgrimage" (Koorep 2016) attracted attention, as the topic of religion at schools is somewhat controversial in Estonia. As the article explained, the reference to pilgrimage originated from the fact that a part of the school excursion followed the Pirita-Vastseliina pilgrimage trail. "This is also a school excursion. Well, you have to go somewhere ..." a pupil said to the newspaper. "Someone just came up with the idea of going hiking," another pupil added. Their English teacher, hearing about the idea and having recently seen a TV program about pilgrimages, decided to change a simple hiking trip into a "pilgrimage." The pupils were given specific roles (retired people, scientists, forest guards), but since they walked on a pilgrimage trail, there were also the roles of atheists, Christians, and yogis.

Although the semisecular/semireligious nature of contemporary pilgrimages is not anything new, this example and a number of others highlight a rather intriguing position of pilgrimages in the Estonian context. While many other religious terms have a negative aura, the fact that the label of pilgrimage is used willingly points to the degree of social desirability. One could draw parallels with words like "scientific" or "eco," which have very positive social value and are therefore used in different realms for marketing purposes. 
It is not clear how and why pilgrimages have acquired solely positive connotations. One possible explanation could be "secularization of language" (Remmel 2017), which denotes the change in the semantics of religion-related terminology. We already noted the occasional negative connotations of religious terms, but another form of that phenomenon is that some religionrelated words seem to have run dry of their "religious" content and are used to indicate "existential importance"; in that respect, religion has become "less religious." There is enough evidence that many initially Christian practices or concepts, such as morality based on the Ten Commandments or cultural heritage, have been detached from Christianity and are perceived as universally human or "European" (Remmel 2019b). This seems to apply to pilgrimages as well, which have lost their meaning as a Christian practice and become one way of dealing with "existential health." This, again, points to religion becoming "less religious," with the references to religion (in our case, pilgrimages) indicating primarily existential importance. This is often the case with "retrospective pilgrimages" (Sepp, forthcoming), whereby it is only afterwards that people start regarding their trip as pilgrimage.

\section{9 Conclusion}

Drawing on case studies, we have identified Caminoization, heritagization, and "bridging" as the prevailing trends in the pilgrimage landscape in contemporary Estonia, where general trends have combined with local peculiarities, which arise mainly, but not exclusively, from the background of the "forced secularization" of the Soviet past. There are influences from the Estonian national narrative, which is critical of Christianity, and Estonia's Lutheran background also plays a particular role. In addition, the development of localized patterns of pilgrimage brings forth the central role of specific individuals, their pilgrimage experiences, and new ideas.

Looking at how Estonian pilgrimages are conducted leaves little doubt that Caminoization has had a huge impact on the local pilgrimage scene. Furthermore, the Camino de Santiago plays a role in shaping the pilgrimage landscape even in the case of pilgrimages that do not reflect the Camino or are in conscious opposition to that type of pilgrimage, representing thus a trend of non-Caminoization. Here the position of Estonia as a border state between East and West is also reflected in pilgrims' search for identity. Drawn toward Orthodoxy, the Mobile Congregation is rather exceptional in the Western-orientated pilgrimage landscape of Estonia.

Together with Caminoization, heritagization has become a common feature of Estonian pilgrimage. In the European context, heritagization often refers 
to the connection with the tradition of historical pilgrimage, while in Estonia the connection has a more national flavor, referring to the connection with Estonian culture of the past, where the role of Christianity is not perceived as unequivocally positive. The strong emphasis on the local, on "Estonianness," raises the question of whether this may be a counterbalance to the idea of a transcultural Europe or perhaps a hidden subscription to some other discourses, such as nature-oriented maausk.

The third facet of Caminoization and heritagization is bridging, whereby pilgrimage or pilgrimage-related activities are used to create a connection between the Church and secular society. While the threshold of the church seems too high and its teachings too restrictive and outdated, it is much easier to fulfill one's spiritual needs in other ways that do not need strong commitment - seen as one of the reasons why alternative spirituality in Estonia is on its way to becoming a mainstream religion (Uibu 2016). Indeed, pilgrimages, too, serve as an example of an easy on-off commitment. Talking about pilgrimage from different perspectives helps to highlight Christian symbols and language; and therefore some pilgrimage activists view their activities as a "soft mission." As contemporary pilgrimage discourse is rather ambiguous and not perceived as uniformly "religious" - especially in the Estonian format of heritagization - we are witnessing attempts to re-Christianize pilgrimage. Even if these attempts are futile, contemporary pilgrimage provides a widely accepted opportunity for Christian practices to live on regardless of (possible) secularization, without a direct connection to "religion," without a package of specific beliefs or identities, disguised as a means for contributing to one's spiritual or existential health.

Glenn Bowman points out that "the sacred" has for the most part remained the locus of pilgrimage studies (Bowman 2014: 153). Estonian examples show that "the sacred" is clearly present in heritagization, but the ambiguous conceptualization of pilgrimage indicates that in the case of "secular" pilgrims, sacredness could be entirely secondary and the focus lies somewhere else. Yet the boundary between "the religious" and "the secular" is rather blurred. Pilgrimage scholars have often reflected on the tourist-pilgrim dichotomy. Particularly in the case of Pirita-Vastseliina pilgrim trail, with its starting point in a working convent and destination in a secular castle, we are reminded of the Turners' famous statement: "A tourist is half a pilgrim, if a pilgrim is half a tourist" (Turner and Turner 1978: 20). Pilgrim and tourist are not, and arguably never have been, either/or categories; thus, it would be more helpful to think of a continuum from tourism to pilgrimage along which people might slide and recalibrate according to circumstances (Coleman and Bowman 2019). It is interesting that even the label of "pilgrim" can have a strong influence on people's behavior, leading to the adoption of "religious" practices such as praying 
without believing in God, or blessing. This, again, points to the contextuality of boundaries between religion and its others, to "on-off religion" (Remmel and Uibu 2015) or "episodic faith" (Percy 2013).

It is clear that pilgrimage is not (yet) perceived as a natural part of Estonian culture, and therefore it remains to be seen whether pilgrim routes with cultural and historical landmarks will alter this. Nevertheless, it is also evident that pilgrimage is free from the usual negative connotations that religion-related topics carry in the Estonian context, having instead even some elements of social desirability. This aspect, along with the different forms of bridging, calls for further investigation, as it may uncover possible conjunctions of the topics of (non)religion, nature, and culture.

\section{Acknowledgement}

The article was written with support from the research project Re-storied Sites and Routes as Inclusive Spaces and Places: Shared Imaginations and Multi-layered Heritage (EMP340), funded by the EEA Financial Mechanism 2014-2021 Baltic Research Program in Estonia; Baltic Sea Foundation grant The Relocation of Transcendence: The Sacred of the Seculars around the Baltic Sea; and Estonian Research Council grant no PRG908 Estonian Environmentalism in the 2oth Century: Ideology, Discourses, Practices. The authors want to express their gratitude to all of the interviewees, and also to the reviewers and editors for their insightful comments.

\section{References}

Aktuaalne Kaamera. 2017. Aktuaalne Kaamera [Tv news program], no. 9o9, 9 September: 14.00-14.06. URL: https://arhiiv.err.ee/vaata/aktuaalne-kaamera-909-232482 (accessed 26 January 2020).

Altnurme, Riho. 2012. "Pilgrimages to Taizé from Estonia." In Antón M. Pazos (ed.), Pilgrims and Politics: Rediscovering the Power of the Pilgrimage, Farnham: Ashgate Publishing, 173-186.

Ammerman, Nancy T. (ed.). 2007. Everyday Religion: Observing Modern Religious Lives. Oxford: Oxford University Press. URL: http://www.oxfordscholarship.com/ view/10.1093/acprof:oso/9780195305418.001.00o1/acprof-9780195305418 (accessed 11 June 2020).

Annus, Epp. 2000. "National Mythology: Past and Present." Interlitteraria 5:115-130. URL: https://www.ceeol.com/search/article-detail?id=187379 (accessed 6 February 2020). 
Bateson, Gregory, and Mary Catherine Bateson. 2005. Angels Fear: Towards An Epistemology of the Sacred. Cresskill, NJ: Hampton Press.

BNS. 2018. "Niguliste kirik jääb muuseumiks ja kontserdisaaliks." BNS. 14 December. URL: https://www.postimees.ee/6477261/niguliste-kirik-jaab-muuseumiks-ja-kont serdisaaliks (accessed 11 June 2020).

Bowman, Glenn. 2014. "Concluding Thoughts." In John Eade and Mario Katić (eds.), Pilgrimage, Politics and Place-Making in Eastern Europe, Farnham: Ashgate, 153-158.

Bowman, Marion, and Tiina Sepp. 2019. "Caminoisation and Cathedrals: Replication, the Heritagisation of Religion, and the Spiritualisation of Heritage." Religion 49(1): 74-98. https://doi.org/10.1080/oo48721X.2018.1515325 (accessed 11 June 2020).

Bowman, Marion, and Ülo Valk (eds.). 2012. Vernacular Religion in Everyday Life: Expressions of Belief. New York: Routledge.

Coelho, Paulo. 2005. The Pilgrimage: Diary of a Magician. London: Harper-Collins Publishers.

Coleman, Simon, and Marion Bowman. 2019. "Religion in Cathedrals: Pilgrimage, Heritage, Adjacency, and the Politics of Replication in Northern Europe." Religion 49(1): 1-23. https://doi.org/10.1080/oo48721X.2018.1515341 (accessed 24 May 2020).

Coleman, Simon, Marion Bowman, and Tiina Sepp. 2019. "A Cathedral Is Not Just for Christmas: Civic Christianity in the Multi-Cultural City." In Pamela E. Klassen and Monique Scheer (eds.), The Public Work of Christmas: Belonging and Difference in Multicultural Societies, Montreal: McGill-Queen's University Press, 240-261.

Coleman, Simon, and John Eade (eds.). 2004. Reframing Pilgrimage: Cultures in Motion. London: Routledge.

Demerath, N. J. 2000. “The Rise of 'Cultural Religion' in European Christianity: Learning from Poland, Northern Ireland, and Sweden." Social Compass 47(1): 127-139. https:// doi.org/10.1177/003776800047001013 (accessed 24 May 2020).

Dionigi, Albera, and John Eade (eds.). 2015. "International Perspectives on Pilgrimage Research: Putting the Anglophone Contribution in Its Place." In Albera Dionigi and John Eade (eds.), International Perspectives on Pilgrimage Studies: Itineraries, Gaps and Obstacles, New York: Routledge, 1-22.

Eade, John, and Michael J. Sallnow. 20oo. Contesting the Sacred: The Anthropology of Pilgrimage. Urbana: University of Illinois Press.

Estonian Census. 2011. URL: http://pub.stat.ee/px-web.20o1/Database/Rahvaloendus/ databasetree.asp (accessed 26 January 2020).

Eurobarometer. 2005. "Special Eurobarometer 225: Wave 63.1 — Social Values, Science \& Technology." Brussels: European Commission. URL: https://ec.europa.eu/com mfrontoffice/publicopinion/archives/ebs/ebs_225_report_en.pdf (accessed 19 May 2020).

Farias, Miguel, Thomas J. Coleman, James E. Bartlett, Lluís Oviedo, Pedro Soares, Tiago Santos, and María del Carmen Bas. 2019. "Atheists on the Santiago Way: Examining 
Motivations to Go on Pilgrimage." Sociology of Religion 8o(1): 28-44. https://doi .org/10.1093/socrel/sryo19.

Frey, Nancy Louise. 1998. Pilgrim Stories. 1st ed. Berkeley: University of California Press. Harrison, Rodney. 2012. Heritage: Critical Approaches. 1st ed. Abingdon: Routledge.

Jaama, Eneli. 2016. "Palveränd — Uus Elustiil Või Reisihullus?" Postimees, 10 July. URL: https://leht.postimees.ee/3745809/palverand-uus-elustiil-voi-reisihullus (accessed 19 May 2020).

Johansen, Paul. 1954. "Das Wunder von Neuhausen in Estland." Zeitschrift für Ostforschung 3(3): 416-422.

Jonuks, Tõnno. 2019. "Nationalism and Prehistoric Religion: Religion in the Creation of Estonian Identity." In Indrek Peedu (ed.), Estonian Study of Religion: A Reader, Tartu: University of Tartu Press, 241-26o.

Jonuks, Tõnno, and Atko Remmel. Forthcoming. "From Nature Romanticism to Eco-Nationalism: The Development of the Concept of Estonians as 'Forest Nation.” Folklore: Electronic Journal of Folklore 2.

Kasselstrand, Isabella. 2015. "Nonbelievers in the Church: A Study of Cultural Religion in Sweden." Sociology of Religion 76(3): 275-294. https://doi.org/10.1093/socrel/ srvo26.

Koorep, Sigrid. 2016. "Klassitäis õpilasi läks palverännakule." Sakala, 31 May. URL: https://sakala.postimees.ee/3714461/klassitais-opilasi-laks-palverannakule (accessed 24 May 2020).

Luengo, Francisco Javier. 2013. "Camino de Santiago y Jóvenes. Oportunidades Pastorales." In Acogida Cristiana y Nueva Evangelización en el Camino de Santiago: Primer Congreso Internacional. Santiago de Compostela: Ocina de Acogida al Peregrino, Catedral de Santiago, 239-255.

Margry, Peter Jan. 2008. “Secular Pilgrimage: A Contradiction in Terms?" In Jan Peter Margry (ed.), Shrines and Pilgrimage in the Modern World: New Itineraries into the Sacred, Amsterdam: Amsterdam University Press, 13-46.

Margry, Peter Jan. 2015. “To Be or Not to Be ... a Pilgrim: Spiritual Pluralism along the Camino Finisterre and the Urge for the End." In Cristina Sánchez-Carretero (ed.), Heritage, Pilgrimage and the Camino to Finisterre: Walking to the End of the World, Cham: Springer, 175-211. https://doi.org/10.1007/978-3-319-20212-9_8.

Niedźwiedź, Anna. 2014. "Competing Sacred Places: Making and Remaking of National Shrines in Contemporary Poland." In John Eade and Mario Katić (eds.), Pilgrimage, Politics and Place-Making in Eastern Europe, Farnham: Ashgate, 79-99.

Österlund-Pötzsch, Susanne. 2010. "Pedestrian Art: The Tourist Gait as Tactic and Performance." Ethnologia Europaea 40(2): 14-28.

Parek, Lagle, Vello Salo, and Ilmo Au. 2012. Pirita Convent AD MMI — MMXI. Tallinn: Pirita Klooster. 
Percy, Martyn. 2013. Anglicanism: Confidence, Commitment, and Communion. Farnham: Ashgate.

Pickel, Gert, Detlef Pollack, and Olaf Müller. 2012. "Differentiated Secularization in Europe: Comparative Results." In Gert Pickel, Detlef Pollack, and Olaf Müller (eds.), The Social Significance of Religion in the Enlarged Europe: Secularization, Individualization and Pluralization, Farnham: Ashgate, 229-256.

Raudvassar, Liina. 2019. "Lagle Parek armastab olla teel." Eesti Kirik, 10 May. U RL: http:// www.eestikirik.ee/lagle-parek-armastab-olla-teel/ (accessed 26 January 2020).

Remmel, Atko. 2017. "Religion, Interrupted? Observations on Religious Indifference in Estonia." In Johannes Quack and Cora Schuh (eds.), Religious Indifference: New Perspectives from Studies on Secularization and Nonreligion, Cham: Springer, 123-142.

Remmel, Atko. 2019a. "(Non)Religion in a Museum: Alterna(rra)tives of the Estonian National Story." Historická Sociologie/Historical Sociology 2: 69-84.

Remmel, Atko. 2019b. "Religiooni uurimisest ilmalikus ühiskonnas." Usuteaduslik Ajakiri 3: 95-126.

Remmel, Atko, and Marko Uibu. 2015. "Outside Conventional Forms: Religion and NonReligion in Estonia." Religion and Society in Central and Eastern Europe 8(1): 5-20.

Ringvee, Ringo. 2017. "Estonia: The Debate on the Role of Religion in a Deeply Secular State." In Jan Nelis, Caroline Sägesser, and Jean-Philippe Schreiber (eds.), Religion and Secularism in the European Union: State of Affairs and Current Debates, Oxford: Peter Lang, 57-62.

Rock, Stella. 2015. "Touching the Holy: Orthodox Christian Pilgrimage Within Russia." In Albera Dionigi and John Eade (eds.), International Perspectives on Pilgrimage Studies: Itineraries, Gaps and Obstacles, New York: Routledge, 47-68.

Roy, Olivier. 2010. Holy Ignorance: When Religion and Culture Part Ways. 1st ed. New York: Columbia University Press.

RTE 2014. "Religioossed suundumused Eestis 2014" (Religious Trends in Estonia 2014).

Survey Database, conducted by Social and Market Research Company EMOR in January-February 2014 (unpublished).

Sánchez-Carretero, Cristina. 2013. "Heritage Regimes and the Camino de Santiago: Gaps and Logics.” In Regina F. Bendix, Aditya Eggert, and Arnika Peselmann (eds.), Heritage Regimes and the State, (Göttingen Studies in Cultural Property), Göttingen: Göttingen University Press, 141-155. URL: http://books.openedition.org/gup/381.

Seljamaa, Elo-Hanna. 2016. "Silencing and Amplifying Ethnicity in Estonia: An Ethnographic Account from Tallinn." Ethnologia Europaea 46(2): 27-43.

Sepp, Tiina. 2007.Peregrina päevik. (Loomingu Raamatukogu). Tallinn:SA Kultuurileht. Sepp, Tiina. 2014. "Pilgrimage and Pilgrim Hierarchies in Vernacular Discourse: Comparative Notes from the Camino de Santiago and Glastonbury." Journal of Ethnology and Folkloristics 8(1): 23-52. 
Sepp, Tiina. 2019. “The Narrative Is Ambiguous and That Location Isn't the Right Location': Presenting and Interpreting Medieval Saints Today in Canterbury, Durham and York." Journal of Ethnology and Folkloristics 13(1): 79-105. https://doi .org/10.2478/jef-2019-0005.

Sepp, Tiina. Forthcoming. "Conducting Fieldwork in Sacred Spaces."

Siim, Pihla Maria. 2016. "Family Stories Untold. Doing Family through Practices of Silence." Ethnologia Europaea 46(2): 74-88.

Smolkin, Victoria. 2018. A Sacred Space Is Never Empty: A History of Soviet Atheism. Princeton, NJ: Princeton University Press.

Stausberg, Michael. 2011. Religion and Tourism: Crossroads, Destinations and Encounters. London: Routledge.

Tamm, Marek. 2008. "History as Cultural Memory: Mnemohistory and the Construction of the Estonian Nation." Journal of Baltic Studies 39(4): 499-516. https://doi.org /10.1080/01629770802468865.

Tarand, Helmut. 1961. "Eessõna." In Vaime Kabur and Helmut Tarand (eds.), Hajutatud mü̈̈did: Eesti kirjamehed religioonist, Tallinn: Eesti Riiklik Kirjastus, 5-28.

Turner, Victor, and Edith Turner. 1978. Image and Pilgrimage in Christian Culture. New York: Columbia University Press.

Uibu, Marko. 2016. "Re-Emerging Religiosity: The Mainstreaming of the New Spirituality in Estonia." Journal of Baltic Studies 47(2): 257-274. https://doi.org/10.108o/o162977 8.2015.1113432.

Vain, Jane. 2015. "Palverännakute kajastamine Eesti sekulaarses ajakirjanduses." вA Thesis, Tallinn: Baltic Methodist Theological Seminary. URL: http://camino.ee/ wp-content/uploads/2015/10/Jane-Vain.-PALVER\%C3\%84NNAKUTE-KAJASTA MINE-EESTI-SEKULAARSES-AJAKIRJANDUSES.-Diplomit $\% \mathrm{C}_{3} \% \mathrm{~B} 6 \% \mathrm{C}_{3} \% \mathrm{~B} 6$ v2.pdf (accessed 26 January 2O2O).

Västrik, Ergo-Hart. 2015. "In Search of Genuine Religion: The Contemporary Estonian Maausulised Movement and Nationalist Discourse." In Kathryn Roundtree (ed.), Contemporary Pagan and Native Faith Movements in Europe: Colonialist and Nationalist Impulses. Oxford: Berghahn, 130-153.

Viilma, Urmas. 2015. "Peapiiskop Viilma: peame tulema kristlastena kapist välja." ERR, 3 December. URL: https://www.err.ee/550248/peapiiskop-viilma-peame-tulema -kristlastena-kapist-valja (accessed 26 January 2020).

Viilma, Urmas. 2019. "Peapiiskop Viilma läbis 315-kilomeetrise palverännuteekonna." $E R R, 11$ November. URL: https://menu.err.ee/1003254/peapiiskop-viilma-labis -315-kilomeetrise-palverannuteekonna (accessed 4 April 2020). 